\title{
INVESTIGATIONS ON ORGANOLEAD COMPOUNDS VI*. TRIPHENYLPLUMBYLSODIUM AND TRIPHENYLPLUMBYLMAGNESIUM HALIDE
}

\author{
L. C. WILLEMSENS AND G. J. M. VAN DER KERK
}

Institute for Organic Chemistry TNO, Utrecht (The Netherlands)

(Received June 9th, 1969)

\section{SUMMARY}

Triphenylplumbylsodium can be prepared from hexaphenyldilead and finely divided sodium in tetrahydrofuran at room temperature while triphenylplumbylmagnesium halide can be conveniently prepared from lead dichloride and phenylmagnesium chloride or bromide in tetrahydrofuran.

These reagents resemble the previously investigated compound triphenylplumbyllithium in many respects. They usually couple readily with reactive halides, but sometimes an exchange reaction is observed. The tendency to exchange increases in the order: $\mathrm{Ph}_{3} \mathrm{PbNa}<\mathrm{Ph}_{3} \mathrm{PbLi}<\mathrm{Ph}_{3} \mathrm{PbMgX}$.

Triphenylplumbylsodium has been previously prepared from triphenyllead chloride or hexaphenyldilead and sodium in liquid ammonia ${ }^{2.3}$ and from tetraphenyllead and sodium in liquid ammonia ${ }^{4}$ :

$$
\begin{aligned}
& \mathrm{Ph}_{3} \mathrm{~Pb}-\mathrm{PbPh}_{3}+2 \mathrm{Na} \rightarrow 2 \mathrm{Ph}_{3} \mathrm{PbNa} \\
& \mathrm{Ph}_{4} \mathrm{~Pb}+2 \mathrm{Na}+\mathrm{NH}_{3} \rightarrow \mathrm{Ph}_{3} \mathrm{PbNa}+\mathrm{NaNH}_{2}+\mathrm{C}_{6} \mathrm{H}_{6}
\end{aligned}
$$

It couples with reactive halides such as ethyl bromide and benzyl chloride to give $\mathrm{Ph}_{3} \mathrm{PbR}$ compounds ${ }^{2-4}$, but no reaction occurs with aryl halides ${ }^{4}$.

Triphenylplumbylmagnesium halide has not yet been described.

We describe here convenient syntheses of these reagents in tetrahydrofuran and compare their reactions with those of triphenylplumbyllithium ${ }^{1,5 a, 6,7}$.

\section{RESULTS AND DISCUSSION}

\section{Preparation of the reagents}

Triphenylplumbylsodium. For some purposes tetrahydrofuran is a more convenient and suitable solvent than liquid ammonia, and we have made triphenylplumbylsodium in tetrahydrofuran by a method analogous to that used for triphenylplumbyllithium $^{1,5 b}$, involving interaction of hexaphenyldilead and sodium. Because

* For Part V see ref. 1. 
the reaction is rather sluggish, the sodium must be very finely divided (sodium sand) if the reaction is to be completed in one night of stirring at room temperature. A dark solution results containing a dark sludge which can be filtered off. A reaction with benzyl chloride gave a yield of $85 \%$ of benzyltriphenyllead. Upon storage, initially some more sludge forms, the solution turns lighter, and the concentration may fall by a few percent, but after a few weeks no further decomposition occurs.

Attempts to prepare triphenylplumbylsodium from lead dichloride and phenylsodium (analogous to a preparation of triphenylplumbyllithium ${ }^{8}$ ) failed. Lead dichloride did not react with phenylsodium prepared ${ }^{9}$ from chlorobenzene and sodium in toluenet. When complexing solvents were added, a vigorous reaction set in which destroyed the phenylsodium. (The Gilman test ${ }^{11}$ became negative; no phenyl-lead compound could be isolated.)

Triphenylplumbylmagnesium chloride and bromide. These reagents are readily prepared in one step from lead dichloride and phenylmagnesium halide in tetrahydrofuran $^{5 c}$ :

$$
\mathrm{PbCl}_{2}+3 \mathrm{PhMgCl} \rightarrow \mathrm{Ph}_{3} \mathrm{PbMgCl}+2 \mathrm{MgCl}_{2}
$$

In tetrahydrofuran the compounds are stable, but in diethyl ether the bromide $\star \star$ soon decomposes with formation of metallic lead. In tetrahydrofuran the Gilman test ${ }^{11}$ is negative whereas in diethyl ether a positive test is observed. Probably, the reagent partly dissociates:

$$
\mathrm{Ph}_{3} \mathrm{PbMgBr} \stackrel{\mathrm{Et}_{2} \mathrm{O}}{\rightleftharpoons} \mathrm{Ph}_{2} \mathrm{~Pb}+\mathrm{PhMgBr}
$$

This suggests that stability is connected with the solvating (electron-donating) power of the solvent:

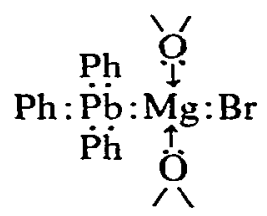

Because tetrahydrofuran is more electron-donating than diethyl ether, the magnesium atom in the tetrahydrofuran complex is electronically more saturated, and so there is less tendency for the phenyl anion to migrate from lead to magnesium.

In organotin chemistry a related phenomenon has recently been observed ${ }^{12}$. Triphenylstannylmagnesium bromide, solvated by triethylamine or diethyl ether, is converted to a dimeric diphenylstannylene/phenylmagnesium bromide complex upon removing the coordinating solvent:

$$
2 \mathrm{Ph}_{3} \mathrm{SnMgBr} \cdot \mathrm{Et}_{3} \mathrm{~N} \rightarrow\left[\mathrm{Ph}_{2} \mathrm{Sn} \cdot \mathrm{PhMgBr}\right]_{2}+2 \mathrm{Et}_{3} \mathrm{~N} \uparrow
$$

\footnotetext{
* Similarly, we found that ether-free phenylmagnesium bromide (prepared from bromobenzene and magnesium in decalin ${ }^{10}$ ) did not react with lead dichloride.

** The stability of the chloride in diethyl ether was not investigated since phenylmagnesium chloride cannot be prepared directly in this solvent.
} 


\section{Reactions}

Hydrolysis. Triphenylplumbylsodium and -magnesium halide completely hydrolyze to lead oxide and benzene (analogous to the hydrolysis of triphenylplumbyllithium $^{1,5 d}$ ):

$$
\mathrm{Ph}_{3} \mathrm{PbM}^{\star}+2 \mathrm{H}_{2} \mathrm{O} \rightarrow \mathrm{PbO}+\mathrm{MOH}+3 \mathrm{C}_{6} \mathrm{H}_{6}
$$

With the sodium reagent a characteristic transient orange-red colour is perceptible which disappears within 2 hours stirring. The magnesium reagent gives a much shorter-lived intermediate, the red colour vanishing within a few seconds. The red species is possibly diphenyllead. This red coloration is useful as a test for triphenylplumbyl-metal reagents.

During hydrolysis no triphenyllead hydride is formed since no $\mathrm{Pb}-\mathrm{H}$ absorption in the $1800 \mathrm{~cm}^{-1}$ region of the infrared spectrum is observed.

Reactions with organic halides. We studied the reactions of the lead-sodium and lead-magnesium reagents with a few organic halides to determine the scope of the coupling reaction, which is of synthetic interest:

$$
\mathrm{Ph}_{3} \mathrm{PbM}+\mathrm{RX} \rightarrow \mathrm{Ph}_{3} \mathrm{PbR}+\mathrm{MX}
$$

The sodium reagent readily couples with reactive halides such as ethyl bromide and benzyl chloride ${ }^{2-4}$. With butyl chloride the reaction at room temperature is much slower, being complete after standing overnight. Carbon tetrachloride gives either (trichloromethyl)triphenyllead ${ }^{5 e}$ or tetrakis(triphenylplumbyl)methane ${ }^{5 e, 6}$, depending on the ratio of the reactants:

$$
\begin{aligned}
& \mathrm{Ph}_{3} \mathrm{PbNa}+\mathrm{CCl}_{4} \rightarrow \mathrm{Ph}_{3} \mathrm{PbCCl}_{3}+\mathrm{NaCl} \\
& 4 \mathrm{Ph}_{3} \mathrm{PbNa}+\mathrm{CCl}_{4} \rightarrow\left(\mathrm{Ph}_{3} \mathrm{~Pb}\right)_{4} \mathrm{C}+4 \mathrm{NaCl}
\end{aligned}
$$

All these results strongly resemble those of triphenylplumbyllithium. However, triphenylplumbylsodium couples with ethyl chloroacetate whereas the lithium analogue gives rise to exchange with formation of hexaphenyldilead ${ }^{5 f}$. This suggests that the sodium derivative is an even better coupling reagent than the lithium compound.

The reactions of the magnesium reagent with organic halides are quite similar to those of the sodium reagent. The reaction with butyl chloride is still slower, not yet being complete after standing overnight at room temperature followed by 3 hours at $50^{\circ}$. Triphenylplumbylmagnesium halide is more liable to exchange reactions than the lithium and sodium analogue, as is illustrated by the reaction with carbon tetrachloride (mole ratio $4 / 1$ ), from which the main product was hexaphenyldilead (exchange product, $49 \%$ ) and only $10 \%$ of the $1 / 1$ coupling product, (trichloromethyl)triphenyllead, was isolated.

The triphenylplumbyl-metal reagents react with 1,2-dihaloethanes to give hexaphenyldilead and ethylene in almost quantitative yields e.g.:

$$
2 \mathrm{Ph}_{3} \mathrm{PbMgCl}+\mathrm{ClCH}_{2} \mathrm{CH}_{2} \mathrm{Cl} \rightarrow \mathrm{Ph}_{6} \mathrm{~Pb}_{2}+\mathrm{H}_{2} \mathrm{C}=\mathrm{CH}_{2} \uparrow+2 \mathrm{MgCl}_{2}
$$

This provides an attractive new method for the preparation of hexaphenyldilead. (For a more detailed discussion of this reaction see Part VII of this series ${ }^{13}$.)

* $\mathrm{M}$ means $\mathrm{Na}$ or $\mathrm{MgX}$ throughout this paper. 
Other reactions. The reaction of both the lead-metal reagents with ethylene oxide takes the expected route ${ }^{58.7}$, giving (2-hydroxyethyl)triphenyllead in good yield :

$$
\mathrm{Ph}_{3} \mathrm{PbM}+\mathrm{H}_{2} \mathrm{C} \stackrel{-\mathrm{O}}{-} \mathrm{CH}_{2} \rightarrow \stackrel{\mathrm{H}_{2} \mathrm{O}}{\longrightarrow} \mathrm{Ph}_{3} \mathrm{PbCH}_{2} \mathrm{CH}_{2} \mathrm{OH}
$$

Triphenylplumbylsodium does not react with benzophenone when kept 14 hours at $50^{\circ}$ (as has also been observed for the lithium analogue ${ }^{14}$ ). If benzyl chloride is subsequently added, a yield of $84 \%$ of benzyltriphenyllead is obtained. This explains why triphenylplumbyl-metal compounds do not respond to the Gilman test ${ }^{11}$, which is based on the formation of a dye upon addition of an organometallic reagent to the $\mathrm{CO}$ bond of $p, p^{\prime}$-bis(dimethylamino)benzophenone.

Conclusion. When comparing the reactions of triphenylplumbyl-metal reagents with phenyl-metal reagents, the following conclusions can be drawn:

(1) Triphenylplumbyl-metal reagents tend to attack carbon-halogen bonds nucleophilically at the carbon atom, thus producing a lead-carbon bond (coupling). On the other hand, phenyl-metal reagents attack the halogen atom, thus giving rise to exchange.

(2) The behaviour with respect to the carbonyl group shows a completely different pattern. The triphenylplumbyl anion does not react at all, whereas in this case the phenyl anion attacks at the carbon atom.

\section{EXPERIMENTAL PART}

\section{Preparation of triphenylplumbylsodium}

All operations were under nitrogen.

A clean piece of sodium ( $2.76 \mathrm{~g}, 120 \mathrm{mg}$-atom, $20 \mathrm{mg}$-atom excess) was melted in $70 \mathrm{ml}$ of dry xylene under nitrogen by heating to $\mathrm{ca} \cdot 110^{\circ}$. After melting the sodium was finely divided by high-speed stirring with a Hershberg stirrer (nichrome wire) while the temperature was slowly lowered. The xylene was replaced by $20 \mathrm{ml}$ of dry tetrahydrofuran. A solution of $43.8 \mathrm{~g}$ of hexaphenyldilead $(50 \mathrm{mmole})$ in $150 \mathrm{ml}$ of tetrahydrofuran was added at once. The sodium was slowly attacked and a green turbidity developed. The temperature rose to $30^{\circ}$. After $24 \mathrm{~h}$ stirring at room temperature all of the sodium had reacted and a dark mixture resulted. A dark sludge was filtered off under nitrogen over dried Filtrapid (a slow process). The dark-coloured filtrate which was constantly kept under nitrogen was added up to $250 \mathrm{ml}$ with tetrahydrofuran. Aliquots of $25 \mathrm{ml}$ were withdrawn for further reactions.

A reaction of $25 \mathrm{ml}$ with $1.3 \mathrm{~g}$ of benzyl chloride $(10 \mathrm{mmole})$ at $-40^{\circ}$ gave $4.5 \mathrm{~g}$ of benzyltriphenyllead ( 8.5 mmole, $85 \%$ ), m.p. $93^{\circ}$ (mixcd m.p.).

\section{Preparation of triphenylplumbylmagnesium halide}

Lead dichloride ( $5.5 \mathrm{~g}, 20$ mmole) was added with stirring to an ice-cooled solution of 62 mmole of phenylmagnesium chloride in $70 \mathrm{ml}$ of tetrahydrofuran. Stirring was continued at room temperature until all the lead dichloride had dissolved (1-2 h). An almost clear, yellow to brown solution resulted.

A reaction with $3 \mathrm{~g}$ of benzyl chloride $(24 \mathrm{mmole})$ at $0^{\circ}$ gave $9 \mathrm{~g}$ of benzyltriphenyllead ( $17 \mathrm{mmole}, 85 \%$ based on $\mathrm{PbCl}_{2}$ ), m.p. $93^{\circ}$.

The bromide was prepared similarly. 
TABLE 1

REACTIONS OF TRIPHENYLPLUMBYLSODIUM AND TRIPHENYLPLUMBYLMAGNESIUM CHLORIDE

\begin{tabular}{|c|c|c|c|c|c|}
\hline \multirow[t]{2}{*}{ Reactant } & \multirow[t]{2}{*}{ Product } & \multicolumn{2}{|c|}{ Yield $(\%)$} & \multirow[t]{2}{*}{ M.p. $\left({ }^{\circ} \mathrm{C}\right)$} & \multirow{2}{*}{$\begin{array}{l}\mathrm{Ph}_{3} \mathrm{PbLi} \\
\text { ref. }\end{array}$} \\
\hline & & $-\mathbf{N a}^{a}$ & $-\mathrm{MgCl}$ & & \\
\hline $\mathrm{H}_{2} \mathrm{O}$ & $\begin{array}{l}\mathrm{PbO} \\
\mathrm{C}_{6} \mathrm{H}_{6}\end{array}$ & 100 & 97 & & $1,5 d$ \\
\hline $\begin{array}{l}\mathrm{PhCH}_{2} \mathrm{Cl} \\
\mathrm{BuCl}\end{array}$ & $\begin{array}{l}\mathrm{Ph}_{3} \mathrm{PbCH}{ }_{2} \mathrm{Ph} \\
\mathrm{Ph}_{3} \mathrm{PbBu} \\
\mathrm{PbO}\end{array}$ & $\begin{array}{c}100^{\circ} \\
91 \\
0\end{array}$ & $\begin{array}{l}85 \\
71 \\
17\end{array}$ & $\begin{array}{l}93 \\
48-49\end{array}$ & $1,5 c$ \\
\hline $\begin{array}{l}\mathrm{CCl}_{4} \\
\frac{1}{4} \mathrm{CCl}_{4}\end{array}$ & $\begin{array}{l}\mathrm{Ph}_{3} \mathrm{PbCCl}_{3} \\
\left(\mathrm{Ph}_{3} \mathrm{~Pb}\right)_{4} \mathrm{C} \\
\mathrm{Ph}_{6} \mathrm{~Pb}_{2} \\
\mathrm{Ph}_{3} \mathrm{PbCCl}_{3} \\
\text { Not characterized }\end{array}$ & $\begin{array}{r}87 \\
51 \\
0 \\
0 \\
?\end{array}$ & $\begin{array}{r}0 \\
49 \\
10 \\
32\end{array}$ & $\begin{array}{l}172-173 \\
289-291 \text { (dec.) } \\
172-173\end{array}$ & $\begin{array}{l}5 \mathrm{e} \\
5 \mathrm{e}, 6\end{array}$ \\
\hline $\mathrm{ClCH}_{2} \mathrm{COOEt}$ & $\begin{array}{l}\mathrm{Ph}_{3} \mathrm{PbCH}_{2} \mathrm{COOEt} \\
\mathrm{Ph}_{6} \mathrm{~Pb}_{2}\end{array}$ & $\begin{array}{r}82 \\
0\end{array}$ & $\begin{array}{r}0 \\
82\end{array}$ & $59-62$ & $5 \Gamma$ \\
\hline $\mathrm{ClCH}_{2} \mathrm{CH}_{2} \mathrm{COOEt}$ & $\begin{array}{l}\mathrm{Ph}_{6} \mathrm{~Pb}_{2} \\
\mathrm{PbO}\end{array}$ & $\begin{array}{l}27 \\
52\end{array}$ & & & $5 f$ \\
\hline $\begin{array}{l}\mathrm{ClCH}_{2} \mathrm{CH}_{2} \mathrm{Cl} \\
\mathrm{BrCH}_{2} \mathrm{CH}_{2} \mathrm{Br}\end{array}$ & $\begin{array}{l}\mathrm{Ph}_{6} \mathrm{~Pb}_{2} \text { (see ref. 13) } \\
\mathrm{Ph}_{6} \mathrm{~Pb}_{2} \text { (see ref. 13) }\end{array}$ & 89 & $\begin{array}{l}94 \\
88\end{array}$ & & 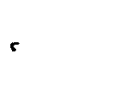 \\
\hline $\begin{array}{l}\mathrm{H}_{2} \mathrm{C}=\frac{-\mathrm{O}-}{\mathrm{Ph}} \\
\mathrm{CH}_{2}\end{array}$ & $\begin{array}{l}\mathrm{Ph}_{3} \mathrm{PbCH}_{2} \mathrm{CH}_{2} \mathrm{OH} \\
\text { No reaction }\end{array}$ & 98 & 82 & & $5 \mathrm{~g}, 7$ \\
\hline
\end{tabular}

${ }^{a}$ Yields are based on the yield of benzyltriphenyllead $(=100 \%) \cdot{ }^{b}$ Triphenylplumbyllithium reacts slowly

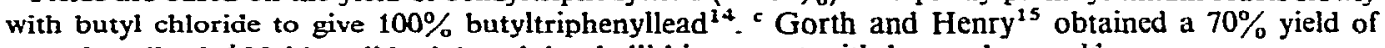
tetraphenyllead. ${ }^{d}$ Neither did triphenylplumbyllithium react with benzophenone ${ }^{\mathrm{It}}$.

\section{Reactions}

The procedures followed were the same as described for reactions of triphenylplumbyllithium. They are summarized in Table 1. For literature see Table 1, last column.

\section{ACKNOWLEDGEMENTS}

This work was sponsored by the International Lead Zinc Research Organization Inc., New York (Director: Dr. Schrade F. Radtke). We are much indebted to Dr. G. M. van der Want for stimulating discussion and to Mr. H. J. H. van der Maas and Mr. G. J. Rotscheid for capable assistance in the experimental work.

\section{REFERENCES}

1 L. C. Willemsens and G. J. M. van der Kerk, J. Organometal. Chem., 15 (1968) 117.

2 H. Gilman and J. C. Bail.ie, J. Amer. Chem. Soc,, 61 (1939) 731.

3 L. S. Foster, W. M. Dix AND I. J. Gruntrest, J. Amer. Chem. Soc., 61 (1939) 1685.

4 H. Gilman and E. Bindschadler, J. Org. Chem., 18 (1953) 1675.

5 L. C. WILlemsens AND G. J. M. VAN DeR KeRK, Investigations in the Field of Organolead Chemistry, Org. Chem. Inst. TNO, Utrecht, ILZRO, New York, 1965; (a) chapter 3 and 4 ; (b) p. 33; (c) p. 20; (d) p. 34 ; (e) p. 41 ; (f) p. 45 ; (g) p. 52. 
6 L. C. Willemsens and G. J. M. van Der Kerk, Rec. Trav. Chim. Pays-Bas, 84 (1965) 43.

7 L. C. Willemsens AND G. J. M. VAN DER KeRK, J. Organometal. Chem., 4 (1965) 34.

8 H. Gilman, L: Summers ANd R. W. Leeper, J. Org. Chem., 17 (1952) 630.

9 J. F. NOBIS AND L. F. MOORMEIER, Ind. Eng. Chem., 46 (1954) 539.

10 D. Bryce-Smith and G. F. Cox, J. Chem. Soc., (1961) 1175.

11 H. Gliman and F. Schulze, J. Amer. Chem. Soc., 47 (1925) 2002.

12 H. M. J. C. Creemers, J. G. Noltes and G. J. M. van der Kerk, J. Organometal. Chem. 14 (1968) 217.

i3 L. C. Willemsens and G. J. M. VAN DER KeRK, J. Organometal. Chem., to be published; TNO, Dutch Patent Application 68/12535, filed Sept. 3, 1968.

14 L. C. WILlemsens, unpublished results.

15 H. Gorth and M. C. HenRy, J. Organometal. Chem., 9 (1967) 117.

J. Organometal. Chem., 19 (1969) 81-86 